\title{
The Possible Role of Herpesviruses in the Pathogenesis of Coronary Atherosclerosis
}

\author{
Julia A. Kotova, PhD*; Veronika I. Shevzova, PhD; Anna A. Zuikova, PhD, ScD; \\ Olga N. Krasnorutskaya, PhD, ScD; Natalia V. Strahova, PhD; Elena Yu. Esina, PhD, ScD \\ Voronezh State Medical University named after N.N. Burdenko \\ Voronezh, the Russian Federation
}

\begin{abstract}
Cardiovascular diseases are still the dominant cause of death worldwide. Coronary artery disease (CAD) is the most common type of heart disease and the leading cause of death for both men and women. Coronary atherosclerosis underlies multiple clinical manifestations ranging from asymptomatic to stable angina, acute coronary syndrome, MI, heart failure, and sudden cardiac death. The prerequisites for a closer study of the pathogenesis of the atherosclerotic process were the development of atherosclerotic vascular lesions at a younger age and the rapid progression of the process. Currently, it is generally accepted that $\mathrm{CAD}$ is a multifactorial disease. Attention is drawn to hereditary disorders of the receptor apparatus, endothelial dysfunction, and lipid metabolism disorders. In addition, latent viral infections are one of the etiopathogenetic factors in the development of atherosclerosis. A number of scientific studies have confirmed the relationship between infectious agents and the development of atherosclerotic vascular lesions. The viral etiology of the development and progression of atherosclerosis is the subject of debate among scientists around the world. (International Journal of Biomedicine. 2021;11(4):391-396.)
\end{abstract}

Key Words: herpesviruses $\bullet$ coronary atherosclerosis $\bullet$ Toll-like receptors $\bullet$ vascular endothelial cells

For citation: Kotova JuA, Shevzova VI, Zuikova AA, Krasnorutskaya ON, Strahova NV, Esina EYu. The Possible Role of Herpesviruses in the Pathogenesis of Coronary Atherosclerosis. International Journal of Biomedicine. 2021;11(4):391-396. doi:10.21103/Article11(4) RA1

\section{Abbreviations}

CAD, coronary artery disease; CA, coronary atherosclerosis; CMV, cytomegalovirus; CRP, C-reactive protein; EBV, EpsteinBarr virus; FCs, foam cells; HSV, herpes simplex virus; HAV, hepatitis A virus; HBV, hepatitis B virus; HCV, hepatitis C virus; ox-LDL, oxidized low-density lipoprotein; MI, myocardial infarction; MMP, matrix metalloproteinases; SMCs, smooth muscle cells; TLRs, Toll-like receptors; TNF- $\boldsymbol{\alpha}$, tumor necrosis factor-alpha; VSMCs, vascular smooth muscle cells; VECs, vascular endothelial cells.

$\mathrm{C}$ oronary atherosclerosis (CA) is one of the main causes of disability and premature death of people all over the world, ${ }^{(1)}$ the development of which can take many years and not have any pronounced symptoms. The first signs of the problem appear in cases when the pathological process is pronounced. During the past decades, our understanding of the pathophysiology of CAD has undergone a remarkable evolution. There are numerous factors involved in the causation of atherosclerosis. Many studies have found a significant association between atherosclerosis and smoking, sedentary lifestyle, hypertension, atherogenic dyslipidemia, genetic factors, and life stress. ${ }^{(2-7)}$ However, about $30 \%$ of patients with atherosclerosis lack identified risk factors, an observation indicating that additional factors predispose to atherosclerosis.

Injury to the vessel wall and the associated inflammatory response to injury are now generally recognized as the essential components of atherogenesis. Among candidates for triggers are ox-LDL and heat shock proteins. Another candidate trigger of both inflammatory and autoimmune responses may be an infection. ${ }^{(8)}$ 
Since the 19th century, it has been suspected that the development of atherosclerotic plaques and their rupture is associated with inflammation caused by infection. The idea that atherosclerosis results from injury to arterial walls traces back to Rudolph Virchow. In 1856, Virchow recognized the inflammatory nature of atherosclerotic plaques. ${ }^{(9)}$ "In some, particularly violent cases the softening manifests itself even in the arteries, not as the consequence of a really fatty process, but as a direct product of inflammation." (10,11)

In the last decades, various studies were conducted on the association between CAD and infectious agents, including viruses. ${ }^{(12-15)}$ In 1983 , Fabricant CG et al. ${ }^{(16)}$ showed that repeated experiments have established that infection with Marek's disease herpesvirus (MDV) leads to atherosclerosis in specific pathogen-free normocholesterolemic chickens.

Currently, many viruses are known to be associated with atherosclerosis. A number of herpes viruses have been identified in atherosclerotic coronary arteries. ${ }^{(17-19)}$ These herpes viruses include CMV (human herpesvirus 5), $\left.{ }^{(20,21}\right)$ EBV(human herpesvirus 4) ${ }^{(22)}$ and HSV(human herpesvirus 1 and 2). ${ }^{(23-25)}$ In addition, the possible role of $\mathrm{HAV},{ }^{(26)} \mathrm{HBV},{ }^{(27)}$ and $\mathrm{HCV}{ }^{(28,29)}$ in the development of CA was also shown.

Although the evidenceis notentirely consistent, infections of vascular wall cells lead to inflammation and atherosclerosis. The mechanism of viral damage to the vascular endothelium is universal. ${ }^{(30)}$ All viruses possess pathogen-associated molecular structures, such as lipopolysaccharides, released by viral RNA, ${ }^{(31)}$ which interact with Toll-like receptors (TLRs) located on the cell membrane of immunocompetent cells. TLRs are major initiators of inflammation. Previous studies involving SNP analysis of TLRs demonstrated that TLRs are involved in the development and progression of diseases like atherosclerosis, cardiac dysfunction in sepsis and congestive heart failure. ${ }^{(30-32)}$

TLR2 promotes atherosclerosis in LDL receptor (LDLr)deficient mice fed a high-fat diet (HFD). ${ }^{(33)}$ In atherosclerosissusceptible low-density lipoprotein receptor-deficient (Ldlr/-) mice, complete deficiency of TLR2 led to a reduction in atherosclerosis. ${ }^{(33)}$ In a study by Curtiss et al., ${ }^{(34)}$ deficiency of TLR1 or TLR6 did not diminish HFD-driven disease. When HFD-fed, LDLr-deficient mice were challenged with Pam3 or MALP2, specific exogenous ligands of TLR2/1 or TLR2/6, respectively, atherosclerotic lesions developed with remarkable intensity in the abdominal segment of the descending aorta.

Michelsen et al. ${ }^{(35)}$ demonstrated that genetic deficiency of TLR4 was associated with a significant reduction of aortic plaque areas in atherosclerosis-prone, APOE-deficient mice, despite persistent hypercholesterolemia, implying an important role for the innate immune system in atherogenesis.

In a study by Ding Y, ${ }^{(36)}$ TLR4 deficiency led to markedly decreased atherosclerosis in obese, TLR4 and LDL receptor double knockout mice. It has been observed that TLR3 has a protective effect on the vascular wall after mechanical and hypercholesterolemia-induced arterial injury. TLR3 plays a critical role in regulating the degradation of the extracellular matrix in lesions, in part by modulation of macrophage MMP2 and -9 activities. ${ }^{(37)}$
Karper et al. ${ }^{(38)}$ showed that blocking TLR7 and TLR9 reduced postinterventional vascular remodeling and foam cell accumulation in hypercholesterolemic APOE*3-Leiden mice.

Thus, the mechanisms of atherogenesis induced by TLRs include the dysfunction of vascular cells, the recruitment of macrophages and other immune cells to the site of vascular injury, the formation of foam cells, and the instability of plaques, while the anti-atherosclerotic effect of TLRs is more in line with its evolutionary conservative function. ${ }^{(39)}$

However, if the general mechanism of the viral contribution to the pathogenesis of CA seems clear, then the study of the specificity of the effect of a wide variety of viral load on the development of CA is at the early stages of research. $^{(17)}$

For example, CMV is widely distributed, can infect blood vessel wall cells, and exhibit the persistence, latency, and recurrence of infection. The infection can indirectly influence the earliest lesions of atherogenesis consisting of intimal accumulations of FCs and T-lymphocytes intermixed with VSMCs. ${ }^{(40)}$ Host defenses to extravascular infections are usually associated with the production of proinflammatory cytokines and cellular adhesion molecules, enhancing leukocyte adhesion.

Studies have linked CMV to three arterial diseases: primary atherosclerosis, post-angioplasty restenosis, and posttransplantation arteriosclerosis. The Atherosclerosis Risk in Communities Study showed that high levels of CMV antibodies were significantly associated with CAD incidents $(\mathrm{RR}=1.76 ; 95 \% \mathrm{CI}: 1.00-3.11)$ during a 5-year follow-up period. ${ }^{(41)}$ In contrast, the Cardiovascular Health Study demonstrated that the risk of MI and CAD death was associated with the presence of IgG antibodies to HSV-1 $(\mathrm{OR}=2.0,95 \% \mathrm{CI}$ : 1.1-3.6) but was not associated with the presence of IgG antibodies to CMV (OR=1.2, 95\% CI: 0.71.9). ${ }^{(42)}$ A study by Zhou et al. found that prior infection with CMV was a strong independent risk factor for restenosis after coronary atherectomy. ${ }^{(43)}$

Sambiase et al. ${ }^{(44)}$ showed a direct role for the CMV in the pathogenesis of accelerated graft coronary atherosclerosis. DNA and/or protein of HSV, HIV, CMV, HCV, EBV, as well as influenza, have been found in atherosclerotic plaques. ${ }^{(13,45)}$

In experimental studies, it was found that CMV infection can induce severe endothelial dysfunction ${ }^{(46,47)}$ and altered response to oxidized lipids in the sub-endothelium, ${ }^{(48)}$ leading to atherosclerosis progression. Thus, replication of CMV in VECs and macrophages ${ }^{(49)}$ triggers the release of proinflammatory cytokines, adhesion molecules, and MMP, as well as cellular death. ${ }^{(50-53)} \mathrm{CMV}$ appears to induce a proliferation of VSMCs by inhibiting the tumor suppression gene p53. ${ }^{(54,55)} \mathrm{CMV}$ and HSV can each have an atherogenic effect, including smooth muscle proliferation, increased expression of cytokines, chemokines, and increased uptake of low-density lipoprotein. ${ }^{(56)}$

Chanouzas et al. ${ }^{(57)}$ showed that the host cellular immune response to $\mathrm{CMV}$ leads to the expansion of cytotoxic CD4+CD28null T-cells that express endothelial homing markers and are independently linked to increased arterial stiffness, a marker of cardiovascular mortality. 
CD4+CD28null T-cells were CMV-specific and expressed a T-helper 1 (Th1) phenotype with high levels of interferongamma (IFN- $\gamma$ ) and TNF- $\alpha$ secretion. As known, IFN- $\gamma$ and TNF- $\alpha$ cytokines mediate inflammation in blood vessel walls through disruption of endothelial junctions and induction of chemokine and adhesion molecule expression on vascular endothelium. This promotes the recruitment and adherence of lymphocytes and monocytes on the inflamed endothelium and facilitates leukocyte transmigration. ${ }^{(58)}$

Apostolou et al. ${ }^{(59)}$ reported that acute infection with EBV was associated with atherogenic lipid changes. The results obtained by Gargouri et al. ${ }^{(60)}$ suggest that lipid peroxidation, protein oxidation, and DNA fragmentation are generally induced during EBV lytic cycle induction.

Many studies have demonstrated possible links between HSV and native atherosclerosis. ${ }^{(24,61-64)} \mathrm{A}$ metaanalysis performed by $\mathrm{Wu}$ et al. ${ }^{(64)}$ indicated that HSV-1 and HSV-2 infections could increase the risk of contracting atherosclerosis. HSV infection of endothelial cells increases endothelial cell synthesis of tissue factor, the rate of thrombin generation on the cell surface, and platelet adherence, while it decreases prostacyclin and thrombomodulin generation. ${ }^{(65-67)}$

In 1990, Key et al. ${ }^{(66)}$ reported two procoagulant consequences of endothelial HSV infection: loss of surface thrombomodulin activity and induction of synthesis of tissue factor, which could contribute to the deposition of thrombi on atherosclerotic plaques and to the "coagulant-necrosis" state.

The nature of the cellular immune response to three human herpesviruses - HSV1, EBV, and CMV-has received considerable attention. ${ }^{(68-71)}$ Some features of these responses suggest they may have significant modulatory effects on the immune system in totum. CMV DNA is present in atherosclerotic and normal vascular tissue, and the anti-CMV immune response may be increased in the context of severe disease..$^{(72,73)}$

The mechanisms whereby CMV might promote atherosclerosis in vivo are not completely clear. Some studies suggest that chronic, unresolved inflammatory responses against latently infected cells distributed systemically or directly in the vessel wall may play a role. ${ }^{(74,75)}$ Alternatively, immunomodulatory proteins secreted by CMV may alter the VSMC motility or macrophage activation within atherosclerotic lesions. ${ }^{(76,78)}$ The latent CMV infection is periodically reactivated, resulting in a chronic immune response or inflammatory response that is damaging to the vascular endothelium and inner membrane, resulting in VSMC proliferation and mutation. ${ }^{(79)}$ The replication of CMV in VECs is the key point of persistent viral infection, transmission, and disease onset, and is the most direct cause of endothelial dysfunction and apoptosis.

The formation of antibody immune complexes of CMV antigen deposited in the vascular wall in the atherosclerotic lesions can induce VECs, macrophages, FCs, VSMCs, and T-lymphocytes to express the monocyte proteins CCL$2,-3,-4$, and -5 and macrophage colony-stimulating factor. $(53,82)$ Moreover, they also stimulate macrophages to produce and release of interleukins IL-1, $-6,-8,-10$, and -12 , TNF- $\alpha$, and other inflammatory cell factors, which cause cellular and humoral immune responses, and accelerate the release of CRP to induce an inflammatory chain-reaction. ${ }^{(78)} \mathrm{A}$ study by Izadi et al. ${ }^{(80)}$ showed that, due to periodic CMV activation in VSMCs caused by local immune responses and inflammation, VSMCs show degeneration and apoptosis caused by inflammatory substances, leading to instability in plaques, which are prone to rupture and bleeding, leading to acute coronary syndrome.

Many viral infections target hemostasis and coagulation, introducing either hemorrhagic or thrombotic complications. ${ }^{(81)}$ There is strong evidence showing abnormal hemostasis linked to inflammation during viral infections in humans. ${ }^{(21,82-84)}$

Thus, the biological characteristics of $\mathrm{CMV}$ are consistent with the CA pathogenesis. ${ }^{(78)} \mathrm{CMV}$ infects VECs, leading to cellular injury and metabolic changes. ${ }^{(85)}$ The activation of latent CMV infection can periodically affect VECs and cause high expression of platelet alpha-granule membrane protein-140, E-selectin, intercellular adhesion molecule-1, vascular cell adhesion molecules, coagulation factors, and other tissue factors. ${ }^{(78)}$ Viruses from VECs then infect VSMCs, and the latent or persistent infection in VSMCs leads to proliferation and the accumulation of cholesterol and cholesterol esters. In infected cells, abnormal apoptotic changes may play an important role in CA pathogenesis. ${ }^{\left({ }^{(6)}\right.}$ The latent CMV infection is periodically reactivated, resulting in a chronic immune response or inflammatory response that is damaging to the vascular endothelium and inner membrane, resulting in VSMC proliferation and mutation. Inflammatory factors can stimulate monocytes to chemotaxis to the vascular wall and differentiate into macrophages, and form FCs through phagocytosis of modified lipoproteins, such as oxLDL. ${ }^{(39)}$ With the development of inflammation, activated leukocytes and VECs can release fibroblast growth-regulating factor, induce the phenotype change of VSMCs, migrate from the middle membrane through the inner elastic layer to the subintimal of arteries, and proliferate and express a large number of cytokines and adhesion factors. ${ }^{(39,62)}$ In the late stage of atherosclerosis, inflammatory cytokines and MMP can degrade extracellular matrix proteins, which make the plaque easy to rupture. In addition, inflammatory cells secrete vascular growth factors, which can promote the formation of blood vessels in the plaque, and eventually lead to MI or stroke. ${ }^{(39,87)}$ Large cohort studies indicate that seropositivity for $\mathrm{CMV}$ or $\mathrm{HCV}$ represents an independent risk marker for cardiovascular diseases. ${ }^{(88,89)}$

\section{Conclusion}

Over the past 30 years, numerous studies provide powerful evidence regarding the involvement of herpesviruses, especially $\mathrm{CMV}$, in the formation of CA. The development of CA is closely related to inflammatory reactions and the immune response, endothelial injury, lipid deposition, metabolic disorders of VSMCs, and coagulation thrombosis. However, the role of viral infection in the development of CA needs further study, since many remaining issues need to be explored and resolved. 


\section{Sources of Funding}

This work was supported by the Council on Grants of the President of the Russian Federation for State Support of Young Scientists and Leading Scientific Schools (Grant MK3435.2021.3.).

\section{Competing Interests}

The authors declare that they have no competing interests.

\section{References}

1. World Health Organization. Prevention of Cardiovascular Disease. Guidelines for assessment and management of cardiovascular risk. Geneva, 2007.

2. Burnett JR. Lipids, lipoproteins, atherosclerosis and cardiovascular disease. Clin Biochem Rev. 2004 Feb;25(1):2.

3. Huszar D, Varban ML, Rinninger F, Feeley R, Arai T, Fairchild-Huntress V, et al. Increased LDL cholesterol and atherosclerosis in LDL receptor-deficient mice with attenuated expression of scavenger receptor B1. Arterioscler Thromb Vasc Biol. 2000 Apr;20(4):1068-73. doi: 10.1161/01.atv.20.4.1068.

4. Mainous AG 3rd, Everett CJ, Diaz VA, Player MS, Gebregziabher M, Smith DW. Life stress and atherosclerosis: a pathway through unhealthy lifestyle. Int J Psychiatry Med. 2010;40(2):147-61. doi: 10.2190/PM.40.2.b.

5. van Leeuwen R, Ikram MK, Vingerling JR, Witteman JC, Hofman A, de Jong PT. Blood pressure, atherosclerosis, and the incidence of age-related maculopathy: the Rotterdam Study. Invest Ophthalmol Vis Sci. 2003 Sep;44(9):3771-7. doi: 10.1167/iovs.03-0121.

6. Kovacic S, Bakran M. Genetic susceptibility to atherosclerosis. Stroke Res Treat. 2012;2012:362941. doi: 10.1155/2012/362941.

7. O'Donnell CJ. Family history, subclinical atherosclerosis, and coronary heart disease risk: barriers and opportunities for the use of family history information in risk prediction and prevention. Circulation. 2004 Oct 12;110(15):2074-6. doi: 10.1161/01.CIR.0000145539.77021.AC.

8. Epstein SE, Zhou YF, Zhu J. Infection and atherosclerosis: emerging mechanistic paradigms. Circulation. 1999 Jul 27;100(4):e20-8. doi: 10.1161/01.cir.100.4.e20.

9. Mayerl C, Lukasser M, Sedivy R, Niederegger H, Seiler R, Wick G. Atherosclerosis research from past to present-on the track of two pathologists with opposing views, Carl von Rokitansky and Rudolf Virchow. Virchows Arch. 2006 Jul;449(1):96-103. doi: 10.1007/s00428-006-0176-7.

10. Virchow R. Cellular Pathology. London: John Churchill; 1858.

11. Libby P. Inflammation in atherosclerosis. Arterioscler Thromb Vasc Biol. 2012 Sep;32(9):2045-51. doi: 10.1161/ ATVBAHA.108.179705.

12. Muhlestein JB, Anderson JL. Chronic infection and coronary artery disease. Cardiol Clin. 2003 Aug;21(3):333-62. doi: 10.1016/s0733-8651(03)00054-7.

13. Rosenfeld ME, Campbell LA. Pathogens and atherosclerosis: update on the potential contribution of multiple infectious organisms to the pathogenesis of atherosclerosis. Thromb Haemost. 2011 Nov;106(5):858-67. doi: 10.1160/ TH11-06-0392.

14. Rupprecht HJ, Blankenberg S, Bickel C, Rippin G, Hafner G, Prellwitz W, et al.; AutoGene Investigators. Impact of viral and bacterial infectious burden on long-term prognosis in patients with coronary artery disease. Circulation. $2001 \mathrm{Jul}$ 3;104(1):25-31. doi: 10.1161/hc2601.091703.

15. Watt S, Aesch B, Lanotte P, Tranquart F, Quentin R. Viral and bacterial DNA in carotid atherosclerotic lesions. Eur J Clin Microbiol Infect Dis. 2003 Feb;22(2):99-105. doi: 10.1007/ s10096-002-0867-1.

16. Fabricant CG, Fabricant J, Minick CR, Litrenta MM. Herpesvirus-induced atherosclerosis in chickens. Fed Proc. 1983 May 15;42(8):2476-9.

17. Lawson JS. Multiple Infectious Agents and the Origins of Atherosclerotic Coronary Artery Disease. Front Cardiovasc Med. 2016 Sep 12;3:30. doi: 10.3389/fcvm.2016.00030.

18. Nikitskaya EA, Maryukhnich EV, Savvinova PP, Pinegina NV, Shpektor AV, Vasilieva EYu, Margolis LB. Human herpesviruses and atherosclerosis. Modern point of view. Creative Cardiology. 2015;2:54-62. doi: 10.15275/ kreatkard.2015.02.05.

19. Yamashiroya HM, Ghosh L, Yang R, Robertson AL Jr. Herpesviridae in the coronary arteries and aorta of young trauma victims. Am J Pathol. 1988 Jan;130(1):71-9.

20. Xenaki E, Hassoulas J, Apostolakis S, Sourvinos G, Spandidos DA. Detection of cytomegalovirus in atherosclerotic plaques and nonatherosclerotic arteries. Angiology. 2009 AugSep;60(4):504-8. doi: 10.1177/0003319708322390.

21. Horváth R, Cerný J, Benedík J Jr, Hökl J, Jelínková I, Benedík J. The possible role of human cytomegalovirus (HCMV) in the origin of atherosclerosis. J Clin Virol. 2000 Feb;16(1):17-24. doi: 10.1016/s1386-6532(99)00064-5.

22. Binkley PF, Cooke GE, Lesinski A, Taylor M, Chen M, Laskowski B, et al. Evidence for the role of Epstein Barr Virus infections in the pathogenesis of acute coronary events. PLoS One. 2013;8(1):e54008. doi: 10.1371/journal.pone.0054008.

23. Kotronias D, Kapranos N. Herpes simplex virus as a determinant risk factor for coronary artery atherosclerosis and myocardial infarction. In Vivo. 2005 Mar-Apr;19(2):351-7.

24. Hajjar DP, Pomerantz KB, Falcone DJ, Weksler BB, Grant AJ. Herpes simplex virus infection in human arterial cells. Implications in arteriosclerosis. J Clin Invest. 1987 Nov;80(5):1317-21. doi: 10.1172/JCI113208.

25. Raza-Ahmad A, Klassen GA, Murphy DA, Sullivan JA, Kinley CE, Landymore RW, Wood JR. Evidence of type 2 herpes simplex infection in human coronary arteries at the time of coronary artery bypass surgery. Can J Cardiol. 1995 Dec;11(11):1025-9.

26. Zhu J, Quyyumi AA, Norman JE, Costello R, Csako $\mathrm{G}$, Epstein SE. The possible role of hepatitis A virus in the pathogenesis of atherosclerosis. J Infect Dis. 2000 Dec;182(6):1583-7. doi: 10.1086/317613. Epub 2000 Oct 13. Erratum in: J Infect Dis 2001 Feb 1;183(3):521.

27. Ishizaka N, Ishizaka $\mathrm{Y}$, Takahashi E, Toda Ei E, Hashimoto H, Ohno M, et al. Increased prevalence of carotid atherosclerosis in hepatitis B virus carriers. Circulation. 2002 Mar 5;105(9):1028-30. doi: 10.1161/hc0902.105718.

28. Butt AA, Xiaoqiang W, Budoff M, Leaf D, Kuller LH, Justice AC. Hepatitis C virus infection and the risk of coronary disease. Clin Infect Dis. 2009 Jul 15;49(2):225-32. doi: $10.1086 / 599371$.

29. Ishizaka N, Ishizaka Y, Takahashi E, Tooda Ei, Hashimoto H, Nagai R, Yamakado M. Association between hepatitis C virus seropositivity, carotid-artery plaque, and intima-media thickening. Lancet. 2002 Jan 12;359(9301):133-5. doi:

*Corresponding author: Julia A. Kotova, PhD Voronezh State Medical University named after N.N. Burdenko. Voronezh, the Russian Federation. E-mail: kotova_u@inbox.ru 
10.1016/s0140-6736(02)07339-7.

30. Sharma S, Garg I, Ashraf MZ. TLR signalling and association of TLR polymorphism with cardiovascular diseases. Vascul Pharmacol. 2016 Dec;87:30-37. doi: 10.1016/j.vph.2016.10.008.

31. Adamczak DM. The Role of Toll-Like Receptors and Vitamin D in Cardiovascular Diseases-A Review. Int J Mol Sci. 2017 Oct 27;18(11):2252. doi: 10.3390/ijms18112252.

32. Tobias P, Curtiss LK. Thematic review series: The immune system and atherogenesis. Paying the price for pathogen protection: toll receptors in atherogenesis. J Lipid Res. 2005 Mar;46(3):404-11. doi: 10.1194/jlr.R400015-JLR200.

33. Mullick AE, Tobias PS, Curtiss LK. Modulation of atherosclerosis in mice by Toll-like receptor 2. J Clin Invest. 2005 Nov;115(11):3149-56. doi: 10.1172/JCI25482.

34. Curtiss LK, Black AS, Bonnet DJ, Tobias PS. Atherosclerosis induced by endogenous and exogenous tolllike receptor (TLR)1 or TLR6 agonists. J Lipid Res. 2012 Oct;53(10):2126-2132. doi: 10.1194/jlr.M028431.

35. Michelsen KS, Wong MH, Shah PK, Zhang W, Yano J, Doherty TM, et al. Lack of Toll-like receptor 4 or myeloid differentiation factor 88 reduces atherosclerosis and alters plaque phenotype in mice deficient in apolipoprotein E. Proc Natl Acad Sci U S A. 2004 Jul 20;101(29):10679-84. doi: 10.1073/pnas.0403249101.

36. Ding Y, Subramanian S, Montes VN, Goodspeed L, Wang $\mathrm{S}$, Han $\mathrm{C}$, et al. Toll-like receptor 4 deficiency decreases atherosclerosis but does not protect against inflammation in obese low-density lipoprotein receptor-deficient mice. Arterioscler Thromb Vasc Biol. 2012 Jul;32(7):1596-604. doi: 10.1161/ATVBAHA.112.249847.

37. Ishibashi M, Sayers S, D'Armiento JM, Tall AR, Welch CL. TLR3 deficiency protects against collagen degradation and medial destruction in murine atherosclerotic plaques. Atherosclerosis. $2013 \mathrm{Jul} ; 229(1): 52-61$. doi: 10.1016/j. atherosclerosis.2013.03.035.

38. Karper JC, Ewing MM, Habets KL, de Vries MR, Peters EA, van Oeveren-Rietdijk AM, et al. Blocking toll-like receptors 7 and 9 reduces postinterventional remodeling via reduced macrophage activation, foam cell formation, and migration. Arterioscler Thromb Vasc Biol. 2012 Aug;32(8):e72-80. doi: 10.1161/ATVBAHA.112.249391.

39. Li B, Xia Y, Hu B. Infection and atherosclerosis: TLRdependent pathways. Cell Mol Life Sci. 2020 Jul;77(14):27512769. doi: 10.1007/s00018-020-03453-7.

40. 40. Ross R. Atherosclerosis--an inflammatory disease. N Engl J Med. 1999 Jan 14;340(2):115-26. doi: 10.1056/ NEJM199901143400207.

41. Sorlie PD, Nieto FJ, Adam E, Folsom AR, Shahar E, Massing M. A prospective study of cytomegalovirus, herpes simplex virus 1, and coronary heart disease: the atherosclerosis risk in communities (ARIC) study. Arch Intern Med. 2000 Jul 10;160(13):2027-32. doi: 10.1001/archinte.160.13.2027.

42. Siscovick DS, Schwartz SM, Corey L, Grayston JT, Ashley $\mathrm{R}$, Wang SP, et al. Chlamydia pneumoniae, herpes simplex virus type 1 , and cytomegalovirus and incident myocardial infarction and coronary heart disease death in older adults: the Cardiovascular Health Study. Circulation. 2000 Nov 7;102(19):2335-40. doi: 10.1161/01.cir.102.19.2335

43. Zhou YF, Leon MB, Waclawiw MA, Popma JJ, Yu ZX, Finkel T, Epstein SE. Association between prior cytomegalovirus infection and the risk of restenosis after coronary atherectomy. N Engl J Med. 1996 Aug 29;335(9):62430. doi: 10.1056/NEJM199608293350903.

44. Sambiase NV, Higuchi ML, Nuovo G, Gutierrez PS,
Fiorelli AI, Uip DE, Ramires JA. CMV and transplantrelated coronary atherosclerosis: an immunohistochemical, in situ hybridization, and polymerase chain reaction in situ study. Mod Pathol. 2000 Feb;13(2):173-9. doi: 10.1038/ modpathol.3880032.

45. Tufano A, Di Capua M, Coppola A, Conca P, Cimino E, Cerbone AM, Di Minno G. The infectious burden in atherothrombosis. Semin Thromb Hemost. 2012 Jul;38(5):51523. doi: $10.1055 / \mathrm{s}-0032-1315759$.

46. Khoretonenko MV, Leskov IL, Jennings SR, Yurochko AD, Stokes KY. Cytomegalovirus infection leads to microvascular dysfunction and exacerbates hypercholesterolemia-induced responses. Am J Pathol. 2010 Oct;177(4):2134-44. doi: 10.2353/ajpath.2010.100307.

47. Gombos RB, Brown JC, Teefy J, Gibeault RL, Conn KL, Schang LM, Hemmings DG. Vascular dysfunction in young, mid-aged and aged mice with latent cytomegalovirus infections. Am J Physiol Heart Circ Physiol. 2013 Jan 15;304(2):H183-94. doi: 10.1152/ajpheart.00461.2012.

48. Carlquist JF, Muhlestein JB, Horne BD, Hart NI, Lim $\mathrm{T}$, Habashi J, et al. Cytomegalovirus stimulated mRNA accumulation and cell surface expression of the oxidized LDL scavenger receptor, CD36. Atherosclerosis. 2004 Nov;177(1):53-9. doi: 10.1016/j.atherosclerosis.2004.07.010. 49. Jarvis MA, Nelson JA. Human cytomegalovirus persistence and latency in endothelial cells and macrophages. Curr Opin Microbiol. 2002 Aug;5(4):403-7. doi: 10.1016/ s1369-5274(02)00334-X.

50. Strååt $\mathrm{K}$, de Klark R, Gredmark-Russ S, Eriksson P, Söderberg-Nauclér C. Infection with human cytomegalovirus alters the MMP-9/TIMP-1 balance in human macrophages. J Virol. 2009 Jan;83(2):830-5. doi: 10.1128/JVI.01363-08.

51. Lunardi C, Dolcino M, Peterlana D, Bason C, Navone R, Tamassia N, et al. Endothelial cells' activation and apoptosis induced by a subset of antibodies against human cytomegalovirus: relevance to the pathogenesis of atherosclerosis. PLoS One. 2007 May 30;2(5):e473. doi: 10.1371/journal.pone.0000473.

52. Popović M, Smiljanić K, Dobutović B, Syrovets T, Simmet T, Isenović ER. Human cytomegalovirus infection and atherothrombosis. J Thromb Thrombolysis. 2012 Feb;33(2):160-72. doi: 10.1007/s11239-011-0662-X.

53. Shen K, Xu L, Chen D, Tang W, Huang Y. Human cytomegalovirus-encoded miR-UL112 contributes to HCMVmediated vascular diseases by inducing vascular endothelial cell dysfunction. Virus Genes. 2018 Apr;54(2):172-181. doi: 10.1007/s11262-018-1532-9.

54. Speir E, Modali R, Huang ES, Leon MB, Shawl F, Finkel T, Epstein SE. Potential role of human cytomegalovirus and p53 interaction in coronary restenosis. Science. $1994 \mathrm{Jul}$ 15;265(5170):391-4. doi: 10.1126/science.8023160.

55. Fan T, Lu H, Hu H, Shi L, McClarty GA, Nance DM,et al. Inhibition of apoptosis in chlamydia-infected cells: blockade of mitochondrial cytochrome c release and caspase activation. J Exp Med. 1998 Feb 16;187(4):487-96. doi: 10.1084/ jem.187.4.487.

56. Zhou YF, Guetta E, Yu ZX, Finkel T, Epstein SE. Human cytomegalovirus increases modified low density lipoprotein uptake and scavenger receptor mRNA expression in vascular smooth muscle cells. J Clin Invest. 1996 Nov 1;98(9):2129-38. doi: 10.1172/JCI119019.

57. Chanouzas D, Sagmeister M, Dyall L, Sharp P, Powley $\mathrm{L}$, Johal S, et al. The host cellular immune response to cytomegalovirus targets the endothelium and is associated with increased arterial stiffness in ANCA-associated vasculitis. 
Arthritis Res Ther. 2018 Aug 29;20(1):194. doi: 10.1186/ s13075-018-1695-8.

58. Ait-Oufella H, Taleb S, Mallat Z, Tedgui A. Recent advances on the role of cytokines in atherosclerosis. Arterioscler Thromb Vasc Biol. 2011 May;31(5):969-79. doi: 10.1161/ ATVBAHA.110.207415.

59. Apostolou F, Gazi IF, Lagos K, Tellis CC, Tselepis AD, Liberopoulos EN, Elisaf M. Acute infection with EpsteinBarr virus is associated with atherogenic lipid changes. Atherosclerosis. 2010 Oct;212(2):607-13. doi: 10.1016/j. atherosclerosis.2010.06.006.

60. Gargouri B, Nasr R, Mseddi M, Benmansour R, Lassoued $\mathrm{S}$. Induction of Epstein-Barr virus (EBV) lytic cycle in vitro causes lipid peroxidation, protein oxidation and DNA damage in lymphoblastoid B cell lines. Lipids Health Dis. $2011 \mathrm{Jul}$ 1;10:111. doi: 10.1186/1476-511X-10-111.

61. Bennett MR, Sinha S, Owens GK. Vascular Smooth Muscle Cells in Atherosclerosis. Circ Res. 2016 Feb 19;118(4):692702. doi: 10.1161/CIRCRESAHA.115.306361.

62. Kutikhin AG, Yuzhalin AE, Brusina EB, Tsitko EA. [The role of viruses in the development of atherosclerosis: evidence from basic research]. Epidemiology and Vaccinal Prevention. 2013;2(69):66-72. [Article in Russian].

63. Melnick JL, Petrie BL, Dreesman GR, Burek J, McCollum $\mathrm{CH}$, DeBakey ME. Cytomegalovirus antigen within human arterial smooth muscle cells. Lancet. 1983 Sep 17;2(8351):644-7. 64. Wu YP, Sun DD, Wang Y, Liu W, Yang J. Herpes Simplex Virus Type 1 and Type 2 Infection Increases Atherosclerosis Risk: Evidence Based on a Meta-Analysis. Biomed Res Int. 2016;2016:2630865. doi: 10.1155/2016/2630865.

65. Visser MR, Tracy PB, Vercellotti GM, Goodman JL, White JG, Jacob HS. Enhanced thrombin generation and platelet binding on herpes simplex virus-infected endothelium. Proc Natl Acad Sci U S A. 1988 Nov;85(21):8227-30. doi: 10.1073/ pnas.85.21.8227.

66. Key NS, Vercellotti GM, Winkelmann JC, Moldow CF, Goodman JL, Esmon NL, et al. Infection of vascular endothelial cells with herpes simplex virus enhances tissue factor activity and reduces thrombomodulin expression. Proc Natl Acad Sci U S A. 1990 Sep;87(18):7095-9. doi: 10.1073/pnas.87.18.7095. 67. Etingin OR, Silverstein RL, Friedman HM, Hajjar DP. Viral activation of the coagulation cascade: molecular interactions at the surface of infected endothelial cells. Cell. 1990 May 18;61(4):657-62. doi: 10.1016/0092-8674(90)90477-v.

68. White DW, Suzanne Beard R, Barton ES. Immune modulation during latent herpesvirus infection. Immunol Rev. 2012 Jan;245(1):189-208.

69. Decman V, Freeman ML, Kinchington PR, Hendricks RL. Immune control of HSV-1 latency. Viral Immunol. 2005;18(3):466-73. doi: 10.1089/vim.2005.18.466.

70. Callan MF. The immune response to Epstein-Barr virus. Microbes Infect. 2004 Aug;6(10):937-45. doi: 10.1016/j. micinf.2004.04.014.

71. Moss P, Khan N. CD $8(+)$ T-cell immunity to cytomegalovirus. Hum Immunol. 2004 May;65(5):456-64. doi: 10.1016/j.humimm.2004.02.014.

72. Nieto FJ, Adam E, Sorlie P, Farzadegan H, Melnick JL, Comstock GW, Szklo M. Cohort study of cytomegalovirus infection as a risk factor for carotid intimal-medial thickening, a measure of subclinical atherosclerosis. Circulation. $1996 \mathrm{Sep}$ 1;94(5):922-7. doi: 10.1161/01.cir.94.5.922.

73. Sorlie PD, Adam E, Melnick SL, Folsom A, Skelton T, Chambless LE, et al. Cytomegalovirus/herpesvirus and carotid atherosclerosis: the ARIC Study. J Med Virol. 1994 Jan;42(1):33-7. doi: 10.1002/jmv.1890420107.
74. Vliegen I, Duijvestijn A, Grauls G, Herngreen S, Bruggeman C, Stassen F. Cytomegalovirus infection aggravates atherogenesis in apoE knockout mice by both local and systemic immune activation. Microbes Infect. 2004 Jan;6(1):17-24.

75. Krebs P, Scandella E, Bolinger B, Engeler D, Miller S, Ludewig B. Chronic immune reactivity against persisting microbial antigen in the vasculature exacerbates atherosclerotic lesion formation. Arterioscler Thromb Vasc Biol. 2007 Oct;27(10):2206-13. doi: 10.1161/ATVBAHA.107.141846.

76. Melnychuk RM, Smith P, Kreklywich CN, Ruchti F, Vomaske J, Hall L, et al. Mouse cytomegalovirus M33 is necessary and sufficient in virus-induced vascular smooth muscle cell migration. J Virol. 2005 Aug;79(16):10788-95.

77. Vliegen I, Duijvestijn A, Stassen F, Bruggeman C. Murine cytomegalovirus infection directs macrophage differentiation into a pro-inflammatory immune phenotype: implications for atherogenesis. Microbes Infect. 2004 Oct;6(12):1056-62.

78. Du Y, Zhang G, Liu Z. Human cytomegalovirus infection and coronary heart disease: a systematic review. Virol J. 2018 Feb 6;15(1):31. doi: 10.1186/s12985-018-0937-3.

79. Horváth R, Cerný J, Benedík J Jr, Hökl J, Jelínková I, Benedík J. The possible role of human cytomegalovirus (HCMV) in the origin of atherosclerosis. J Clin Virol. 2000 Feb;16(1):17-24. doi: 10.1016/s1386-6532(99)00064-5.

80. Izadi M, Fazel M, Saadat SH, Nasseri MH, Ghasemi M, Dabiri $\mathrm{H}$, et al. Cytomegalovirus localization in atherosclerotic plaques is associated with acute coronary syndromes: report of 105 patients. Methodist Debakey Cardiovasc J. 2012 AprJun;8(2):42-6. doi: 10.14797/mdcj-8-2-42.

81. Beristain-Covarrubias N, Perez-Toledo M, Thomas MR, Henderson IR, Watson SP, Cunningham AF. Understanding Infection-Induced Thrombosis: Lessons Learned From Animal Models. Front Immunol. 2019 Nov 5;10:2569.

82. Kohler JA, Munoz FM, Goss JA, Miloh TA. Viral upper respiratory infection at pediatric liver transplantation is associated with hepatic artery thrombosis. Liver Transpl. 2017 Nov;23(11):1477-1481. doi: 10.1002/lt.24866.

83. Yang Y, Tang H. Aberrant coagulation causes a hyperinflammatory response in severe influenza pneumonia. Cell Mol Immunol. 2016 Jul;13(4):432-42. doi: 10.1038/cmi.2016.1.

84. Cui S, Fu Z, Feng Y, Xie X, Ma X, Liu T, et al. The disseminated intravascular coagulation score is a novel predictor for portal vein thrombosis in cirrhotic patients with hepatitis B. Thromb Res. 2018 Jan;161:7-11.

85. Rahbar A, Söderberg-Nauclér C. Human cytomegalovirus infection of endothelial cells triggers platelet adhesion and aggregation. J Virol. 2005 Feb;79(4):2211-20.

86. Taveira A, Ponroy N, Mueller NJ, Millard AL. Entry of human cytomegalovirus into porcine endothelial cells depends on both the cellular vascular origin and the viral strain. Xenotransplantation. 2014 Jul-Aug;21(4):324-40.

87. Doyle B, Caplice N. Plaque neovascularization and antiangiogenic therapy for atherosclerosis. J Am Coll Cardiol. 2007 May 29;49(21):2073-80. doi: 10.1016/j.jacc.2007.01.089. 88. Haji SA, Starling RC, Avery RK, Mawhorter S, Tuzcu EM, Schoenhagen P, et al. Donor hepatitis-C seropositivity is an independent risk factor for the development of accelerated coronary vasculopathy and predicts outcome after cardiac transplantation. J Heart Lung Transplant. 2004 Mar;23(3):27783. doi: 10.1016/S1053-2498(03)00148-7.

89. Simanek AM, Dowd JB, Pawelec G, Melzer D, Dutta A, Aiello AE. Seropositivity to cytomegalovirus, inflammation, all-cause and cardiovascular disease-related mortality in the United States. PLoS One. 2011 Feb 17;6(2):e16103. doi: 10.1371/journal.pone.0016103. 